\title{
Kemampuan Baca Tulis Al-Quran dan Korelasinya terhadap Kemampuan Matematika Mahasiswa Prodi Tadris Matematika IAIN Palopo
}

\author{
${ }^{1}$ Hasri \\ ${ }^{2}$ Nur Rahmah \\ 1,2 Institut Agama Islam Negeri (IAIN) Palopo \\ Jl. Agatis, Balandai, Kota Palopo, Sulawesi Selatan, Indonesia \\ E-mail:2nur rahmah@iainpalopo.ac.id
}

\begin{abstract}
This research is quantitative correlations designed ex-post facto. The population is all students of mathematics department from 2012/2013 until 2014/2015 IAIN Palopo totaling 291 people. The sampling technique used was proportional random sampling with a sample of 73 students. The collection data using by documentation and test. The result showed that: (1). The overview of the literacy al - Quran is 53 students from 73 have a very high ability (72,5\%). This means that the literacy Quran students in terms of known/recognize letters hijaiyah, able to read the Quran and write some verses in the Quran have been classified as very good. (2). The mathematical ability is 50 students from 73 have a very high ability (68,5\%). Thin means that that the ability of students in terms of reasoning, inductive reasoning, comprehension, problem solving, connections, communication, analytical thinking and creative thinking as well as a very good analogy are included, and (3). The ability to read and write Quran student has a significant correlation with math skills. This is based on the results of hypothesis testing inferential analysis that showed a correlation coefficient $r=$ 0608 and the coefficient of determination $r^{2}=0.3697$ or $36.97 \%$. Interpretation of results is quite or moderate
\end{abstract}

Keywords: Literacy of Quran, Mathematics skill

\begin{abstract}
Abstrak
Penelitian ini merupakan kuntitatif korelasional yang didesain secara ex-post facto. Populasinya adalah seluruh mahasiswa matematika mulai dari angkatan 2012/2013 sampai dengan angkatan 2014/2015 IAIN Palopo yang berjumlah 291 orang. Teknik pengambilan sampel yang digunakan adalah proporsional random sampling dengan jumlah sampel 73 orang. Teknik pengumpulan data dilakukan dengan menggunakan dokumentasi dan tes.. Hasil penelitian menunjukkan bahwa (1) kemampuan baca tulis al-qur'an mahasiswa menujukkan skor rata-rata sebesar 87.1096 dengan frekuensi 53 orang berada pada kategori sangat tinggi (72.5\%). Hal ini berarti bahwa kemampuan baca tulis al-qur'an mahasiswa dalam hal mengetahui/mengenal huruf-huruf hijaiyah, mampu membaca al-qur'an dengan benar serta mampu menulis beberapa ayat dalam al-qur'an sudah tergolong sangat bagus; (2) Tingkat kemampuan mahasiswa menunjukkan skor rata-rata sebesar 86.2877 dengan frekuensi 50 orang berada pada kategori sangat tinggi (68.5\%). Hal ini berarti bahwa kemampuan mahasiswa dalam hal penalaran, penalaran induktif, pemahaman, pemecahan masalah, koneksi, komunikasi, berpikir analitis dan berpikir kreatif serta analogi sudah termasuk sangat baik; dan (3) Kemampuan baca tulis al-qur'an mahasiswa memiliki korelasi yang signifikan dengan kemampuan matematikanya. Hasil analisis inferensial menunjukkan bahwa koefisien korelasi $r=0.608$ dan koefisien determinasi $r^{2}=0.3697$ atau $36.97 \%$. Hasil interpretasi tergolong cukup atau sedang.
\end{abstract}

Kata Kunci: Kemampuan Baca Tulis Al-Quran, Kemampuan Matematika 


\section{Pendahuluan}

Pengajaran Al-Qur'an merupakan pondasi utama pengajaran bagi disiplin ilmu. Pentingnya kemampuan dasar ini akan lebih mudah, bila diterapkan kepada semua umat islam pada usia dini. Karena pada masa-masa itu, fikiran dan hati mereka masih bersih dan suci.

Di samping itu penguasaan matematika dalam menunjang keberhasilan pembangunan sangat besar, karena pendidikan matematika tidak hanya memungkinkan seseorang dapat menggunakan matematika dalam berbagai aspek kehidupan sehari-hari, tetapi juga menumbuhkan kemampuan yang dapat digunakan dimasa yang akan datang. Mengingat pentingnya peranan matematika dalam kehidupan manusia, maka untuk meningkatkan penguasaan matematika di setiap jenjang pendidikan perlu mendapat perhatian serius dari semua pihak yang berkecimpung dalam dunia pendidikan matematika. Selain itu pula, di perguruan tinggi khususnya perguruan tinggi agama islam perlu adanya pelajaran Al Qur'an, hanya saja waktu dan sarananya terbatasi, materi yang diberikan kepada mahasiswa terbatas, apalagi jika mahasiswa yang belajar itu berasal dari program studi matematika, sehingga intensitas belajar baca tulis al-qur'an tidak sama dengan mahasiswa yang memilih program studi PAI.

Berdasarkan observasi awal yang dilakukan terhadap mahasiswa program studi tadris matematika, terkadang kemampuan mereka dalam memahami matematika berbanding terbalik dengan kemampuan memahami baca tulis al-qur'an, kemampuan penalaran matematika mahasiswa kadangkala tidak ekivalen dengan kemampuan baca tulis al-qur'an yang mereka miliki, sehingga sering terjadi dikotomi antara mahasiswa yang bisa baca tulis al-qur'an dengan mahasiswa yang memiliki kemampuan matematika. Karena pentingnya pengetahuan tentang Al -Qur'an, maka peneliti berusaha mengangkat masalah ini menjadi obyek pembahasan penelitian dengan maksud untuk mengetahui korelasi antara keduanya, yaitu korelasi antara kemapuan baca tulis al-qur'an mahasiswa dengan kemampuan matematikanya.

\section{Kerangka Teoretis}

\section{Hakikat Belajar}

Belajar merupakan aktivitas yang dilakukan seseorang untuk mendapatkan perubahan dalam dirinya melalui pelatihan-pelatihan atau pengalaman-pengalaman. Seorang ibu yang mengikuti seminar tentang pengaturan uang keluarga akan mendapatkan pengetahuan tentang bagaimana mengelola uang keluarga. Sebelum seseorang bisa mengendarai sepeda, ia belajar lebih dahulu bagaimana caranya mengendarai sepeda. Dari 
contoh tersebut, jelaslah bahwa belajar bukan hanya aktivitas yang dilakukan oleh pelajar saja, melainkan juga ibu rumah tangga dan yang lainnya.

Dengan demikian, belajar dapat membawa perubahan bagi si pelaku, baik perubahan pengetahuan, sikap, maupun keterampilan. Dengan perubahan-perubahan tersebut, tentunya si pelaku juga akan terbantu dalam memecahkan permasalahan hidup dan bisa menyesuaikan diri dengan lingkungannya.

\section{Kemampuan Baca Tulis Al-Quran}

Salah satu yang membedakan manusia dengan makhluk yang lainnya adalah kemampuannya untuk belajar. Untuk itu, Allah memberikan akal sehat sebagai alat untuk belajar, sehingga membuat manusia mampu menjadi pemimpin. Aktivitas belajar sangat terkait dengan proses pencairan ilmu. Islam sangat menekankan terhadap pentingnya ilmu. Al-quran dan Hadis mengajak kaum Muslim mencari dan mendapatkan ilmu dan kearifan, serta menempatkan orang-orang yang berpengetahuan pada drajat yang tinggi.

Beberapa ayat pertama yang diwahyukan kepada Rasulullah, menyebutkan pentingnya membaca, pena, dan ajaran manusia.

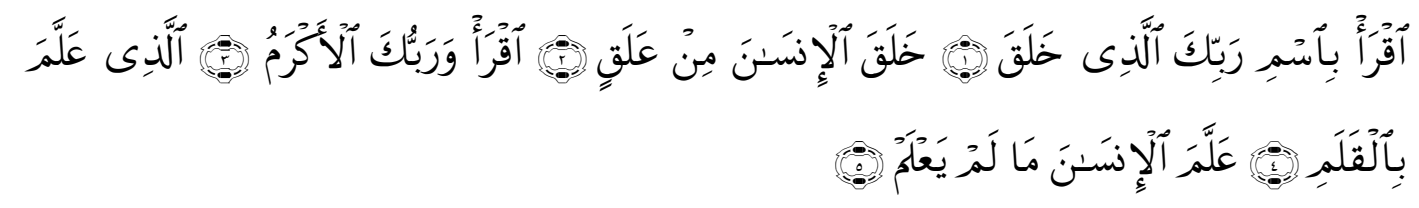

Artinya :

"Bacalah dengan (menyebut) nama Tuhanmu yang Menciptakan, Dia Telah menciptakan manusia dari segumpal darah. Bacalah, dan Tuhanmulah yang Maha pemurah, Yang mengajar (manusia) dengan perantaran kalam[1589], Dia mengajar kepada manusia apa yang tidak diketahuinya. (Q.S Al-'Alaq [96]:1-5)."

\section{Kemampuan Matematika}

Yang termasuk ke dalam kemampuan matematika antara lain dijelaskan sebagai berikut:

1. Kemampuan Penalaran Matematika

2. Kemampuan Penalaran Induktif

3. Kemampuan Pemahaman Matematika

4. Kemampuan Koneksi Matematik

5. Kemampuan Komunikasi Matematika

6. Kemampuan Berpikir Analitis

7. Kemampuan Berfikir Kreatif

8. Kemampuan Analogi Matematika 


\section{Metode Penelitian}

Pendekatan yang digunakan dalam penelitian ini adalah pendekatan kuantitatif. Penelitian ini merupakan penelitian korelasional yang didesain secara ex-post facto. Kerlinger di dalam buku yang ditulis oleh Sukardi mendefinisikan bahwa penelitian ex-post facto merupakan penelitian dimana variable-variabel bebas telah terjadi ketika peneliti mulai dengan pengamatan variable terikat dalam suatu penelitian. Adapun desain penelitian yang dimaksud dalam penelitian ini dapat digambarkan sebagai berikut:

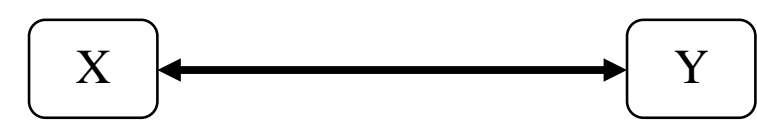

dengan:

$\mathrm{X}$ : Kemampuan baca tulis al-quran

Y : Kemampuan matematika mahasiswa

Populasi dalam penelitian ini adalah seluruh mahasiswa Program Studi Tadris Matematika IAIN Palopo yang berjumlah 291 orang yang tersebar ke dalam beberapa angkatan mulai dari angkatan 2012/2013 sampai dengan angkatan 2014/2015. Teknik pengambilan sampel yang digunakan adalah teknik proporsional random sampling dengan menggunakan rumus sebagai berikut:

$$
s p l=\frac{n}{N} x j s
$$

dengan:

$s p l=$ Jumlah sampel pada tiap-tiap sub populasi

$n=$ Jumlah responden dalam sub populasi

$\mathrm{N}=$ Jumlah responden dalam populasi

js $=$ Jumlah sampel yang dibutuhkan ${ }^{1}$

Sumber data yang digunakan dalam penelitian ini ada dua, yaitu: data primer dan data sekunder. Data primer adalah data yang peneliti dapatkan secara langsung dari lapangan. Data primer yang dimaksud adalah data tes kemampuan baca tulis al-qur'an mahasiswa dan data tes kemampuan matematika mahasiswa. Sedangkan data sekunder adalah data yang peneliti dapatkan dari sumber tertulis atau referensi lain. Data sekunder yang dimaksud dalam penelitian ini yaitu data dari prodi terkait mahasiswa pendidikan matematika berasal dari latar belakang pendidikan sebelumnya (SMU/SMK/MAN/MAK).

\footnotetext{
${ }^{1}$ Bambang Soepono, Statistik Terapan (Jakarta: Rineka Cipta, 2007).
} 
Kemampuan Baca Tulis Al-Quran

Hasil analisis berkaitan dengan skor kemampuan baca tulis al-qur'an mahasiswa program studi pendidikan matematika disajikan pada Tabel 1 berikut

Tabel 1 statistik distribusi skor kemampuan baca tulis al-qur'an

\begin{tabular}{|c|c|}
\hline Statistik & Nilai Statistik \\
\hline Ukuran sampel & 73 \\
Skor maksimum & 98.00 \\
Skor minimum & 64.00 \\
Rentang skor & 43.00 \\
Skor rata-rata & 87.1096 \\
Standar deviasi & 8.38411 \\
\hline
\end{tabular}

Berdasarkan Tabel 1 tersebut ditunjukkan bahwa dari 73 orang responden, memiliki skor rata-rata 87.1096, dengan skor maksimum 98.00 dan skor minimum 64.00 dan standar deviasi 8.38411. Jika skor variabel kemampuan baca tulis al-qur'an di atas dikelompokkan ke dalam lima kategori, maka diperoleh distribusi frekuensi serta persentase seperti yang ditunjukkan pada Tabel 2 berikut:

Tabel 2 distribusi frekuensi dan persentase kemampuan baca tulis al-qur'an

\begin{tabular}{|c|c|c|c|c|}
\hline No & Skor & Kategori & Frekuensi & Persentase (\%) \\
\hline 1 & $0 \leq \mathrm{x} \leq 34$ & Sangat Rendah & 0 & 0 \\
2 & $35 \leq \mathrm{x} \leq 54$ & Rendah & 0 & 0 \\
3 & $55 \leq \mathrm{x} \leq 64$ & Sedang & 1 & 1.4 \\
4 & $65 \leq \mathrm{x} \leq 84$ & Tinggi & 19 & 26.1 \\
5 & $85 \leq \mathrm{x} \leq 100$ & Sangat Tinggi & 53 & 72.5 \\
\hline
\end{tabular}

Berdasarkan Tabel 2 di atas menunjukkan bahwa tidak ada mahasiswa yang berada pada kategori sangat rendah (0\%) dan rendah (0\%). Hanya terdapat 1 orang mahasiswa yang berada pada kategori sedang dengan persentase $1.4 \%, 19$ orang mahasiswa yang berada pada kategori tinggi dengan persentase $26.1 \%$, serta $72.5 \%$ berada pada kategori sangat tinggi dengan frekuensi 53 orang mahasiswa. Dengan demikian dapat dikatakan bahwa skor variabel kemampuan baca tulis al-qur'an mahasiswa berada pada kategori sangat tinggi 
Kemampuan Matematika Mahasiswa

Hasil analisis berkaitan dengan skor kemampuan matematika disajikan pada Tabel 3 berikut:

Tabel 3 statistik distribusi skor kemampuan matematika

\begin{tabular}{|c|c|}
\hline Statistik & Nilai Statistik \\
\hline Ukuran sampel & 73 \\
Skor maksimum & 95.00 \\
Skor minimum & 70.00 \\
Rentang skor & 25.00 \\
Skor rata-rata & 86.2877 \\
Standar deviasi & 8.28734 \\
\hline
\end{tabular}

Sumber data: Hasil analisis data dengan SPSS Ver.16,00 for windows

Berdasarkan Tabel 3 di atas menunjukkan bahwa dari 73 orang responden, memiliki skor rata-rata 86.2877 , dengan skor maksimum 95.00 dan skor minimum 70.00 dan standar deviasi 8.28734. Jika skor variabel kemampuan matematika di atas dikelompokkan ke dalam lima kategori, maka diperoleh distribusi frekuensi serta persentase seperti yang ditunjukkan pada tebel 4 berikut:

Tabel 4 distribusi frekuensi dan persentase kemampuan matematika

\begin{tabular}{|c|c|c|c|c|}
\hline No & Skor & Kategori & Frekuensi & Persentase (\%) \\
\hline 1 & $0 \leq \mathrm{x} \leq 34$ & Sangat Rendah & 0 & 0 \\
2 & $35 \leq \mathrm{x} \leq 54$ & Rendah & 0 & 0 \\
3 & $55 \leq \mathrm{x} \leq 64$ & Sedang & 0 & 0 \\
4 & $65 \leq \mathrm{x} \leq 84$ & Tinggi & 23 & 31.5 \\
5 & $85 \leq \mathrm{x} \leq 100$ & Sangat Tinggi & 50 & 68.5 \\
\hline
\end{tabular}

Berdasarkan table 4 di atas menunjukkan bahwa tidak ada mahasiswa yang berada pada kategori sangat rendah (0\%), rendah (0\%) dan sedang (0\%). Mahasiswa yang berada pada kategori tinggi memiliki frekuensi 23 orang dengan persentase $31.5 \%$, serta $68.5 \%$ berada sangat tinggi dengan frekuensi 50 orang mahasiswa. Dengan demikian dapat dikatakan bahwa skor variabel kemampuan matematika mahasiswa berada pada kategori sangat tinggi. 


\section{Analisis Inferensial dan Pembahasan}

Berdasarkan uji normalitas dengan menggunakan uji Kolmogorov Smirnoz diperoleh bahwa data kemampuan baca tulis al-quran dan kemampuan matematika mahasiswa terdistribusi normal. Demikian pula dipeoleh bahwa uji homogenitas terpenuhi.

Selanjutnya untuk menguji hipotesis, kriteria pengujiannya yaitu $\mathrm{H}_{0}$ diterima jika $r_{\text {hitung }} \leq r_{\text {tabel }}$ dan $\mathrm{H}_{0}$ ditolak jika $r_{\text {hitung }}>r_{\text {tabel }}$. Berdasarkan hasil perhitungan statistik nilai koefisien korelasi $r_{\text {hitung }} 0.608$ dan nilai $r_{\text {tabel }}$ 0.227 , maka diperoleh $r_{\text {hitung }}>r_{\text {tabel }}$. Hal ini menunjukkan adanya korelasi yang signifikan antara kedua variabel tersebut. Dalam hal ini $\mathrm{H}_{0}$ ditolak dan $\mathrm{H}_{1}$ diterima. Dengan demikian, dapat dikatakan bahwa terdapat hubungan yang signifikan antara kemampuan baca tulis al-qur'an dengan kemampuan matematika mahasiswa program studi pendidikan matematika IAIN Palopo.

Hasil analisis deskriptif merupakan gambaran mengenai kemampuan baca tulis al-qur'an dan kemampuan matematika mahasiswa prodi matematika IAIN Palopo. Dari hasil analisis tersebut diperoleh bahwa kemampuan baca tulis al-qur'an mahasiswa berada pada kategori sangat tinggi dengan skor rata-rata 87.1096. adapun indikator kemampuan baca tulis al-qur'an mahasiswa dilihat dari kemampuan mengetahui/mengenal huruf-huruf hijaiyah, mampu membaca al-qur'an dengan benar dan mampu menulis beberapa ayat-ayat dalam al-qur'an. Namun demikian, mahasiswa harus tetap berusaha untuk mengasah dan menjaga kemampuan itu dengan membiasakannya dalam aktifitas sehari-hari. Karena tanpa pembiasaan, maka kemampuan itu tidak ada artinya sama sekali. Apalagi hal ini berkaitan dengan keislaman dan keimanan seorang mahasiswa.

Berdasarkan pemaparan pada tinjauan pustaka bahwa Al Qur'an merupakan Kalamullah (kitab suci) yang diturunkan kepada Nabi Muhammad sebagai mu'jizat yang terbesar, dimana didalamnya terdapat pedoman dalam mencapai kebahagiaan hidup yang hakiki. Maka kewajiban setiap muslim di seluruh penjuru dunia untuk membaca, menghayati, serta mengamalkannya. Keterampilan membaca al-Qur'an atau lebih dikenal dengan istilah mengaji merupakan keterampilan penting pada fase awal guna memahami isi kandungan al-Qur'an. Mengaji juga memiliki keterkaitan erat dengan ibadah-ibadah ritual kaum muslim, seperti pelaksanaan shalat, haji dan kegiatan-kegiatan berdo'a lainnya. Dalam pelaksanaan sholat atau haji misalnya, tidak sah hukumnya bila menggunakan bahasa selain bahasa alQur'an (Bahasa Arab). 
Pengajaran Al-Qur'an merupakan pondasi utama pengajaran bagi disiplin ilmu. Pentingnya kemampuan dasar ini akan lebih mudah, bila diterapkan kepada semua umat islam pada usia dini. Karena pada masa-masa itu, fikiran dan hati mereka masih bersih dan suci. Selain itu, hasil analisis deskriptif menunjukkan bahwa kemampuan matematika mahasiswa prodi matematika IAIN Palopo berada pada kategori sangat tinggi pula dengan skor rata-rata 86.2877. Indikator yang diperhatikan dalam penelitian ini adalah kemampuan penalaran matematika, kemampuan penalaran induktif, pemahaman matematika, pemecahan masalah, koneksi, komunikasi, berpikir analitis, berpikir kreatif dan analogi matematika. Hal ini menjadi sebuah prestasi yang membanggakan dan sekaligus menjadi tantangan bagi mahasiswa untuk tetap mempertahankan kemampuan tersebut. Oleh karena kemampuan matematika erat kaitannya dengan analisis dan penalaran sehingga mahasiswa matematika diharapkan mampu menggunakannya dalam kehidupannya.

Koefisien determinasi menunjukkan bahwa korelasi antara kemampuan baca tulis al-qur'an dan kemampuan matematika mahasiswa sebesar 0.3697. hal ini berarti $36.97 \%$ variansi kemampuan baca tulis alqur'an dapat dijelaskan dengan hubungan linearnya yaitu kemampuan matematika. Demikian pula sebaliknya. Sedangkan 63.1\% dapat ditentukan oleh variabel-variabel lain yang tidak diselidiki dalam penelitian ini.

Gambaran korelasi antara kemampuan baca tulis al-qur'an dan kemampuan matematika mahasiswa tergolong cukup atau sedang jika bersumber dari interpretasi nilai $r$. Hal ini berarti kemampuan baca tulis alqur'an mahasiswa tidak sepenuhya berpengaruh terhadap kemampuan matematikanya. Demikian pula sebaliknya, kemampuan matematika mahasiswa juga tidak sepenuhnya berpengaruh terhadap kemampuan baca tulis al-qur'annya. Ada faktor-faktor lain yang dapat mempengaruhi keduanya. Oleh karena itu, sangat penting kiranya agar mahasiswa mampu memadukan kedua kemampuan tersebut, sehingga menjadi nilai lebih bagi mahasiswa program studi pendidikan matematika.

Berbagai upaya dapat dilakukan baik oleh lembaga maupun mahasiswa yang bersangkutan terkait dengan permasalahan tersebut. Salah satu upaya yang mungkin dapat dilakukan oleh lembaga adalah dengan lebih mengintenskan penyelenggaraan kegiatan ma'had ali sebagai sarana untuk meningkatkan kemampuan baca tulis al-qur'an mahasiswa khusunya program studi tadris matematika IAIN Palopo. Dari sini, kegiatan baca tulis al0quran diharapkan lebih terkontrol dan terarah di bawah bimbingan pengajar yang berkualitas dan berkompeten. Semnetara itu, bagi diri mahasiswa juga dapat meningkatkan kompetensi baca tulis al-qur'annya dengan mengikuti pengajian-pengajian tingkat mahasiswa atau 
menggalakkan forum diskusi dan sharing yang lebih terfokus kepada upaya peningkatan kemampuan baca tulis al-quran, dan lain sebagainya. Upaya lain juga mungkin dapat dilakukan oleh HMPS tadris matematika IAIN Palopo untuk mewadahi aktifitas mahasiswa tadris matematika IAIN Palopo khusunya bagi mahasiswa yang mengalami kendala dalam meningkatkan kompetensi baca tulis al-quran dan kompetensi matematika mereka.

\section{Penutup}

Berdasarkan pembahasan yang telah diuraikan tersebut, maka dapat disimpulkan beberapa hal sebagai berikut:

1. Gambaran kemampuan baca tulis al-qur'an mahasiswa program studi tadris matematika IAIN Palopo berdasarkan analisis data yang telah dilakukan terhadap 73 orang responden menujukkan skor rata-rata sebesar 87.1096 dengan frekuensi 53 orang berada pada kategori sangat tinggi (72.5\%). Hal ini berarti bahwa kemampuan baca tulis al-qur'an mahasiswa dalam hal mengetahui/mengenal huruf-huruf hijaiyah, mampu membaca al-qur'an dengan benar serta mampu menulis beberapa ayat dalam al-qur'an sudah tergolong sangat bagus.

2. Tingkat kemampuan matematika mahasiswa program studi tadris matematika IAIN Palopo berdasarkan data yang diperoleh dan dianalisis, menunjukkan skor rata-rata sebesar 86.2877 dengan frekuensi 50 orang berada pada kategori sangat tinggi (68.5\%). Hal ini berarti bahwa kemampuan mahasiswa dalam hal penalaran, penalaran induktif, pemahaman, pemecahan masalah, koneksi, komunikasi, berpikir analitis dan berpikir kreatif serta analogi sudah termasuk sangat baik.

Kemampuan baca tulis al-qur'an mahasiswa tadris matematika IAIN Palopo memiliki korelasi yang signifikan dengan kemampuan matematikanya. Hal ini berdasarkan pada hasil analisis inferensial uji hipotesis yang menunjukkan nilai koefisien korelasi $r=0.608$ dan koefisien determinasi $r^{2}=0.3697$ atau $36.97 \%$. Hasil interpretasi tergolong cukup atau sedang.

\section{Daftar Pustaka}

Arikunto, Suharsimi. Prosedur Penelitian Suatu Pendekatan Praktik. Jakarta: Rineka Cipta, 2007.

Bambang Soepono. Statistik Terapan. Jakarta: Rineka Cipta, 2007.

BSNP. Standart Isi Untuk Satuan Pendidikan Dasar Dan Menengah. Jakarta, 2006.

Daulay, Putra, and Haidar. Pendidikan Islam Dalam Sistem Pendidikan Nasional Di Indonesia. Jakarta: Kencana, 2004.

Riduwan. Dasar-Dasar Statistika. Bandung: Alfabeta, 2009.

Subana. Statistika Pendidikan. Bandung: Pustaka Setia, 2002.

Sudjono, Anas. Pengantar Statistik Pendidikan. Jakarta: Rajawali Press, 2009. 
Sugiyono. Metode Penelitian Administrasi. Bandung: Alfabeta, 2005.

-_- Statistika Untuk Penelitian. Bandung: Alfabeta, 2009.

Sukardi. Metodologi Penelitian Pendidikan. Jakarta: Bumi Aksara, 2004.

Wahyuni, Esa Nur, and Baharuddin. Teori Belajar \& Pembelajaran. Jogjakarta: Ar-Ruzz Media, 2009. 